\title{
Action of Atrial Natriuretic Peptide in the Immature Ovine Kidney
}

\author{
PETER SHINE, JOHN G. MCDOUGALL, MICHELLE K. TOWSTOLESS, AND \\ E. MARELYN WINTOUR \\ Department of Physiology and Howard Florey Institute of Experimental Physiology and Medicine, University of \\ Melbourne, Parkville, Victoria, Australia
}

\begin{abstract}
This study examines the effects of infused human atrial natriuretic peptide 1-28 (hANP) on ovine fetal renal function. hANP was infused into chronically cannulated ovine fetuses of 103-128 days gestation (term $142-152$ days) at $1.1(4), 2.2(5)$, and $4.4(5) \mu \mathrm{g} / \mathrm{h}$ for $2 \mathrm{~h}$. Isotonic saline was infused in 10 control experiments. The fractional reabsorption of infused lithium was used as a marker of proximal tubular sodium reabsorption. Glomerular filtration rate and urinary water and electrolyte excretion were assessed. The blood pressure and heart rate were unaltered by any dose of hANP. The lowest dose (1.1 $\mu \mathrm{g} / \mathrm{h})$ did not produce any significant changes in glomerular filtration rate, urinary electrolyte or water excretion, or fractional reabsorption of lithium. hANP, at $4.4 \mu \mathrm{g} / \mathrm{h}$, caused a significant $(p<0.001) 5$-fold increase in the excretion of $\mathrm{Na}, \mathrm{Cl}$, and $\mathrm{Ca}$, doubled the excretion rate of $K$ and free water clearance, and significantly increased glomerular filtration rate. Fractional sodium reabsorption and fractional reabsorption of lithium were significantly decreased $(p<0.001,<0.01$, respectively). The results show that the fetal kidney, at this stage, is as responsive to hANP as is the adult kidney. The natriuretic action of $h A N P$ is related to increases in glomerular filtration rate and proximal tubular rejection of sodium (as assessed by fractional reabsorption of lithium). The excessive salt loss of the premature or low birth weight neonate, which also involves increased delivery of filtrate to the distal tubule, may be due to endogenous hANP, circulating at high concentrations. (Pediatr Res 22: 11-15, 1987)
\end{abstract}

\section{Abbreviations}

hANP, human atrial natriuretic peptide 1-28

GFR, glomerular filtration rate

$F_{R_{N}}$, fractional reabsorption of sodium

$\mathbf{F R}_{\mathrm{I}, \mathrm{i}}$, fractional reabsorption of lithium

$\mathrm{U}_{\mathrm{Na}}, \mathrm{K}, \mathrm{Cl}, \mathrm{Ca} \mathrm{V}$, renal excretion rate of sodium/potassium/ chloride/calcium

$\mathrm{C}_{1120}$, free water clearance

AVP, arginine vasopressin

$C_{L,}$, clearance of lithium

MAP, mean arterial pressure

HR, heart rate
It is well established that the premature or very low birth weight baby cannot maintain normal sodium balance on a standard salt intake (1-3). The lower the gestational age at delivery the more likely it is that the problem will occur (1). This suggests that the inability to retain a normal percentage of the dietary salt intake is somehow related to the level of immaturity of the kidney. One suggestion has been that the immature kidney is relatively insensitive to the sodium-retaining effect of the endogenous aldosterone (4). However, it has been shown that one feature of the defect is that a larger than normal percentage of the renal filtrate is delivered to the distal tubule, suggesting that too little filtrate is reabsorbed in the proximal tubule (2). The site of action of aldosterone is the distal tubule and so insensitivity to aldosterone cannot wholly account for the natriuresis. We have suggested previously that the renal function of the premature or growth-retarded neonate might resemble that of the fetus rather than that of the normal newborn, and shown that cortisol has a unique natriuretic effect in the immature ovine fetal kidney (5). The immature fetal kidney is less responsive to endogenous or exogenous AVP than is the kidney of the nearterm fetus $(6,7)$. With the discovery of an endogenous natriuretic peptide of atrial origin $(8,9)$ it seemed to be important to find out whether this peptide exerted any influence over sodium handling by the immature fetal kidney. This became more potentially important as it was reported that the concentration in fetal blood exceeded that in maternal blood (10). We therefore examined the effect of three infusion rates of hANP in chronically cannulated ovine fetuses early in the last third of gestation.

It has been suggested that the $C_{\mathrm{Li}}$ can be used to provide information about the delivery of sodium and water from the proximal tubule to later segments of the nephron $(11,12)$. Even though this has not been rigorously established in the adult or fetal sheep, there is a good correlation between the amounts of lithium and sodium reabsorbed in the proximal tubule of other species $(11,12)$ and so $C_{\mathrm{Li}}$ was measured in these experiments, as well as GFR and the excretory rates of $\mathrm{Na}, \mathrm{K}, \mathrm{Cl}, \mathrm{Ca}$, and water.

\section{MATERIALS AND METHODS}

Animals. The fetuses of 14 cross-bred Merino ewes of known mating dates were used for these studies. The fetuses were cannulated, as described previously (7), between 96 and 105 days of gestation (term in this group of sheep is $145-152$ days). Cannulae were inserted under general anaesthesia ( $2 \%$ halothane in oxygen) in one carotid artery, one jugular vein, and transabdominally into the bladder, the ends stoppered, and brought to the exterior through a flank incision in the ewe. No experiments were performed until at least 7 days postoperatively, and experiments were only commenced when the fetal urine osmolality was less than $175 \mathrm{mosmol} / \mathrm{kg}$ water. At this urine osmolality the fetus was known to be in the optimal unstressed condition (13).
Received November 21,1986 ; accepted January 28,1987 . Melbourne, Parkville, 3052, Victoria, Australia.

Supported by grants from the National Health and Medical Research Counci of Australia to the Howard Florey Institute of Experimental Physiology and Medicine. M.K.T. is supported by a scholarship from the Sudden Infant Death Research Foundation of Australia. 
Daily blood gases and hematocrits were measured and all values were in the normal range at the commencement of each experiment (13). All experiments were performed in fetuses of 103128 days of gestation. Not all fetuses received all three infusion rates of hANP but each fetus that received at least one hANP infusion was also subject to a control experiment when vehicle only was infused.

Experimental protocol. On the day of the experiment fetal urine was drained for at least $30 \mathrm{~min}$ and then discarded. Hourly urine collections were made for the subsequent $6 \mathrm{~h}$, during which time a solution of sterile isotonic saline containing $0.5 \mu \mathrm{Ci} / \mathrm{ml}$ of ${ }^{51} \mathrm{Cr}$-EDTA and $54 \pm 0.6(25) \mathrm{mmol} / \mathrm{liter}(\mathrm{mean} \pm \mathrm{SEM}, n$ ) $\mathrm{Li}$ was infused at $1.9 \mathrm{ml} / \mathrm{h}$, using a Braun Perfusor VI pump. The 1st $h$ was the equilibration period, the $2 \mathrm{nd} h$ the control period, and in the control experiments no hANP was added. In the test experiments hANP, synthesized in the Howard Florey Institute by Wade et al. (14), was added to the infusate in sufficient concentration to produce infusion rates of the peptide of $1.1,2.2$, or $4.4 \mu \mathrm{g} / \mathrm{h}$, for $2 \mathrm{~h}$. The ANP was not infused for the last $2 \mathrm{~h}$ of the 6 -h period, which served as postcontrol periods. Fetal arterial blood samples $(2.2 \mathrm{ml})$ were collected at the midpoint of each urine collection period for the estimation of plasma osmolality, electrolytes, Li, and ${ }^{51} \mathrm{Cr}$-EDTA concentrations. A total of $13 \mathrm{ml}$ blood was removed from each fetus over the 6-h period. Each sample was immediately replaced with an equivalent volume of isotonic saline. Throughout the entire experimental period MAP and HR were recorded from the arterial cannula, using a Gould Statham transducer.

Sample analysis. Plasma and urine osmolalities were measured by freezing point depression in an Advanced Osmometer (model 3CII). $\mathrm{Na}$ and $\mathrm{K}$ concentrations were measured on a Beckman System E2A Electrolyte Analyzer; Cl was measured using standard Technicon Autoanalyzer techniques; urine ionized $\mathrm{Ca}$ concentrations were measured by a Radiometer $1 \mathrm{CA} 1$ Ionized Calcium Analyzer. The concentration of ${ }^{51} \mathrm{Cr}$-EDTA, in urine and plasma, was assessed by counting in a Packard Autogamma Spectrometer 5210.

$\mathrm{Li}$ was measured in plasma and urine using a Varian Spectra AA-40 atomic absorption spectrophotometer. The plasma blank was $0.04 \pm 0.01,(17) \mathrm{mmol} /$ liter (mean $\pm \mathrm{SEM}, n$ ), while the urine blank was indistinguishable from zero. Fetal urines were diluted $1 / 50$ and plasma $1 / 10$ with an ionization suppressant consisting of $\mathrm{K}$ at a final concentration of $2 \mathrm{mg} / \mathrm{ml}$ in deionized water with $0.1 \%$ Triton X-100. The interassay coefficent of variation determined by 20 assays of a standard plasma was $8.87 \%$. The rate of infusion was such that all plasma values fell between 0.2 and $0.3 \mathrm{mmol} /$ liter.

GFR was calculated from the standard formula: U.V/P for ${ }^{51} \mathrm{Cr}$-EDTA.

$\mathrm{C}_{\mathrm{H} 2 \mathrm{O}}$ was calculated from the formula:

$$
\mathrm{C}_{\mathrm{H} 2 \mathrm{O}}=\mathrm{V}-\frac{\mathrm{U}_{\mathrm{osm}} \cdot \mathrm{V}}{\mathrm{P}_{\mathrm{osm}}}
$$

Fractional $\mathrm{Na}$ and $\mathrm{Li}$ reabsorption rates were calculated by the formulas:

$$
\mathrm{FR}_{\mathrm{Na} / \mathrm{Li}}=\frac{\mathrm{GFR} \cdot \mathrm{P}_{\mathrm{Na} / \mathrm{Li}}-\mathrm{U}_{\mathrm{Na} / \mathrm{Li}} \cdot \mathrm{V}}{\mathrm{GFR} \cdot \mathrm{P}_{\mathrm{Na} / \mathrm{Li}}}
$$

Statistics. Data were analyzed on a Series I computer by a two-way analysis of variance with $t$ test for multiple comparison of specific time points.

\section{RESULTS}

The infusion of hANP, at any of the three rates, was not associated with any significant change in fetal mean arterial blood pressure. The mean arterial blood pressure was $43.5 \pm 1.92(5)$ $\mathrm{mm} \mathrm{Hg}$, in the control period at the highest dose, and was 45.3 \pm 1.2 and $42.7 \pm 0.9 \mathrm{~mm} \mathrm{Hg}$, respectively, during the infusion of hANP at $4.4 \mu \mathrm{g} / \mathrm{h}$. Heart rates over the same three periods were $184.8 \pm 4.5,183.4 \pm 5.0$, and $186 \pm 7.0$ beats $/ \mathrm{min}$, respectively, in the five fetuses. Values are mean \pm SEM, $n$.

The results for $U_{\mathrm{Na}} \mathrm{V}$ and GFR are shown in Figure 1. The results are graphed in four horizontal panels with the control infusions at the top in panel $A$, and the increasing doses of hANP in $B, C$, and $D$. There as no statistically significant change in $\mathrm{U}_{\mathrm{Na}} \mathrm{V}$ or GFR over the $5 \mathrm{~h}$ of saline infusion in the controls or during the infusion of hANP at the lowest dose, $1.1 \mu \mathrm{g} / \mathrm{h}$. There was a significant increase $(p<0.05)$ in $\mathrm{U}_{\mathrm{Na}} \mathrm{V}$ during the $2 \mathrm{nd} \mathrm{h}$ of the $2.2-\mu \mathrm{g} / \mathrm{h}$ dose and significant increases at both the $1 \mathrm{st}(p$ $<0.05)$ and 2 nd $\mathrm{h}(p<0.001)$ at the $4.4-\mu \mathrm{g} / \mathrm{h}$ dose of hANP. GFR was significantly increased at both the 1 st and 2 nd $h$ of the highest dose $(p<0.001)$. The maximum increase in $\mathrm{U}_{\mathrm{Na}} \mathrm{V}$ was from $0.38 \pm 0.09(5) \mathrm{mmol} / \mathrm{h}$ to $2.11 \pm 0.47(5)$, where values are the mean $\pm \operatorname{SEM}(n)$. The maximum increase in GFR was more modest, from $1.27 \pm 0.05$ to $1.77 \pm 0.08 \mathrm{ml} / \mathrm{min}$.

As shown in Figure 2, a similar pattern was seen with $U_{K} V$ as with $U_{\mathrm{Na}} \mathrm{V}$. The maximum increase in $\mathrm{U}_{\mathrm{K}} \mathrm{V}$ was a rise from 0.06 \pm 0.02 to $0.13 \pm 0.03 \mathrm{mmol} / \mathrm{h}$. $\mathrm{C}_{\mathrm{H} 2 \mathrm{O}}$ increased significantly $(p$ $<0.01$ ) during both hours of hANP infusion at the rate of 4.4
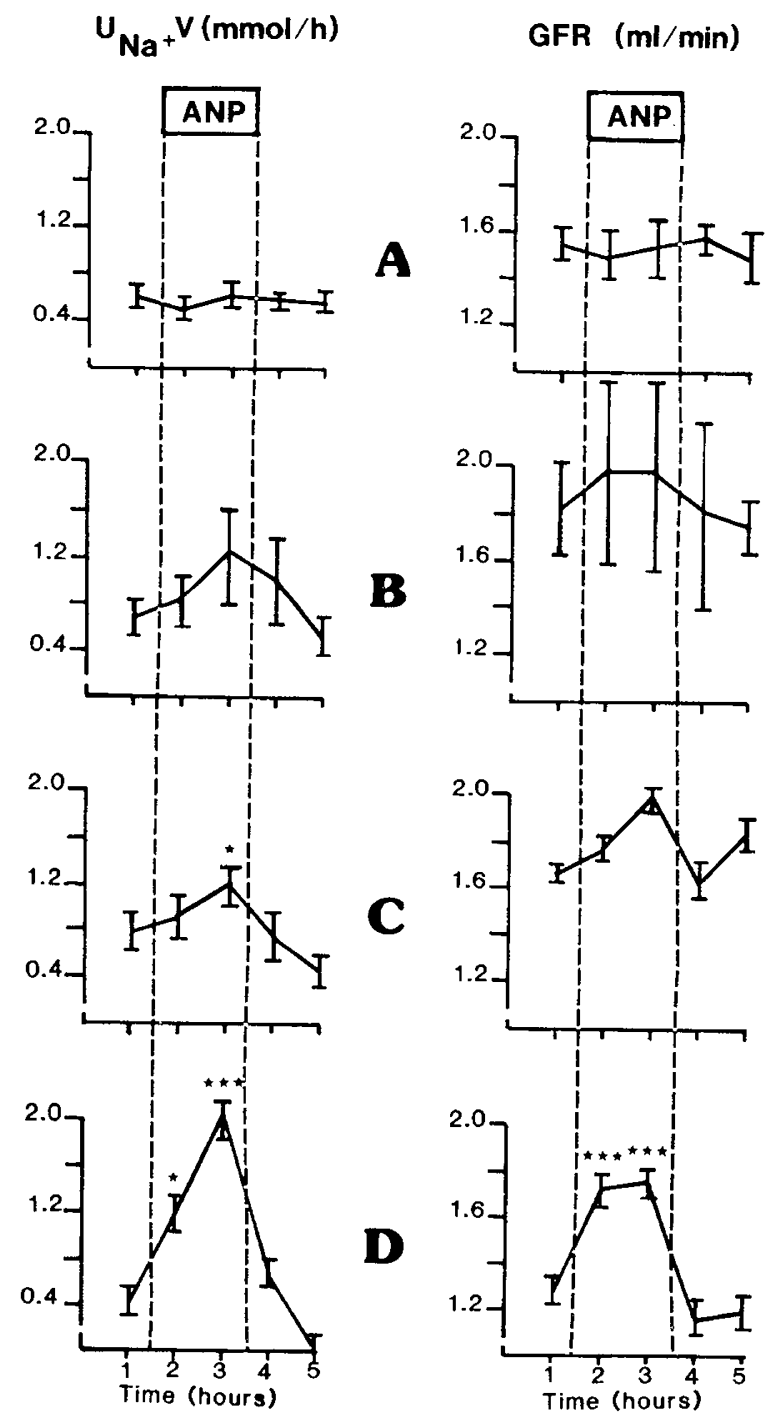

Fig. 1. The values for $\mathrm{U}_{\mathrm{Na}} \mathrm{V}$ (left) and GFR (right) for ovine fetuses infused at varying rates of hANP. $A, 0(n=10) ; B, 1.1 \mu \mathrm{g} / \mathrm{h}(n=4) ; C$, $2.2 \mu \mathrm{g} / \mathrm{h}(n=5) ; D, 4.4 \mu \mathrm{g} / \mathrm{h}(n=5)$. hANP infusion lasted for $2 \mathrm{~h}$ during broken lines, after 1 -h control period and before 2-h postcontrol periods. Fetuses were 103-128 days of gestation, term is $145-152$ days. Values are mean \pm SEM. ${ }^{*} p<0.05 ;{ }^{* *} p<0.01 ;{ }^{* * *} p<0.001$. 

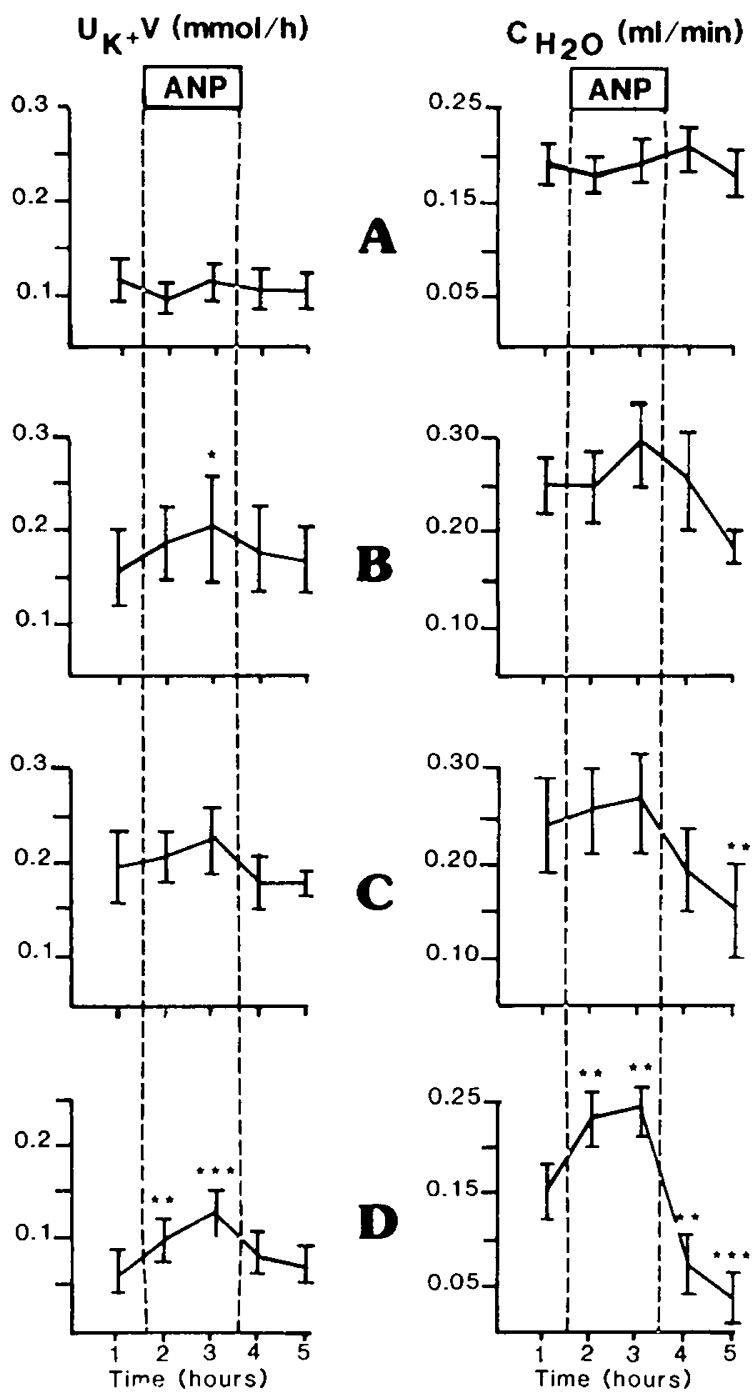

Fig. 2. The values for $\mathrm{U}_{\mathrm{K}} \mathrm{V}$ (left) and $\mathrm{C}_{\mathrm{H} 2 \mathrm{O}}$ (right) in ovine fetuses infused with hANP at varying rates. $A, O(n=10) ; B, 1.1 \mu \mathrm{g} / \mathrm{h}(n=5)$; $C, 2.2 \mu \mathrm{g} / \mathrm{h}(n=5) ; D, 4.4 \mu \mathrm{g} / \mathrm{h}(n=5)$. hANP infusions lasted for $2 \mathrm{~h}$ between the broken lines, following a 1-h control period, and before a 2$\mathrm{h}$ postcontrol period. Fetuses were 103-108 days of gestation. Values are mean \pm SEM. ${ }^{*} p<0.05 ;{ }^{* *} p<0.01 ;{ }^{* * *} p<0.001$.

$\mu \mathrm{g} / \mathrm{h}$, as shown in Figure 2, and subsequently decreased to values significantly below control values. This increase was due solely to an increase in flow rate as urine osmolality increased from $125.8 \pm 12.5(5)$ to $137.6 \pm 8.6(5)$ and $164 \pm 10.3(5) \mathrm{mosmol} /$ $\mathrm{kg}$ water during the $2 \mathrm{~h}$ of hANP infusion at $4.4 \mu \mathrm{g} / \mathrm{h}$.

$\mathrm{U}_{\mathrm{Ca}} \mathrm{V}$ increased significantly during the $2 \mathrm{nd} \mathrm{h}$ of both the 2.2 and $4.4-\mu \mathrm{g} / \mathrm{h}$ infusions of hANP $(p<0.01)$ and the maximum reached was $18.6 \pm 6.9(5) \mu \mathrm{mol} / \mathrm{h}$ from a control value of 4.4 $\pm 0.9 \mu \mathrm{mol} / \mathrm{h}$ (Fig. 3). $\mathrm{U}_{\mathrm{Cl}} \mathrm{V}$ increased maximally, at the highest dose, from $0.22 \pm 0.03$ to $1.57 \pm 0.33 \mathrm{mmol} / \mathrm{h}$.

Fractional reabsorption of $\mathrm{Na}$ was unchanged in the control saline infusion and decreased significantly by the 2 nd $h$ of infusion of hANP at 1.1, $2.2(p<0.05)$, and $4.4 \mu \mathrm{g} / \mathrm{h}(p<$ $0.001)$. The fractional reabsorption of $\mathrm{Li}$ was decreased most significantly at the $4.4-\mu \mathrm{g} / \mathrm{h}$ dose of hANP $(p<0.01)$ (Fig. 4$)$.

\section{DISCUSSION}

The major finding herein is that the ovine fetal kidney, by the beginning of the last third of gestation, is sensitive to the natriuretic effect of hANP. If we assume that the fetuses in this study weighed between 1 and $2 \mathrm{~kg}$ then the infusion rate of $4.4 \mu \mathrm{g} / \mathrm{h}$

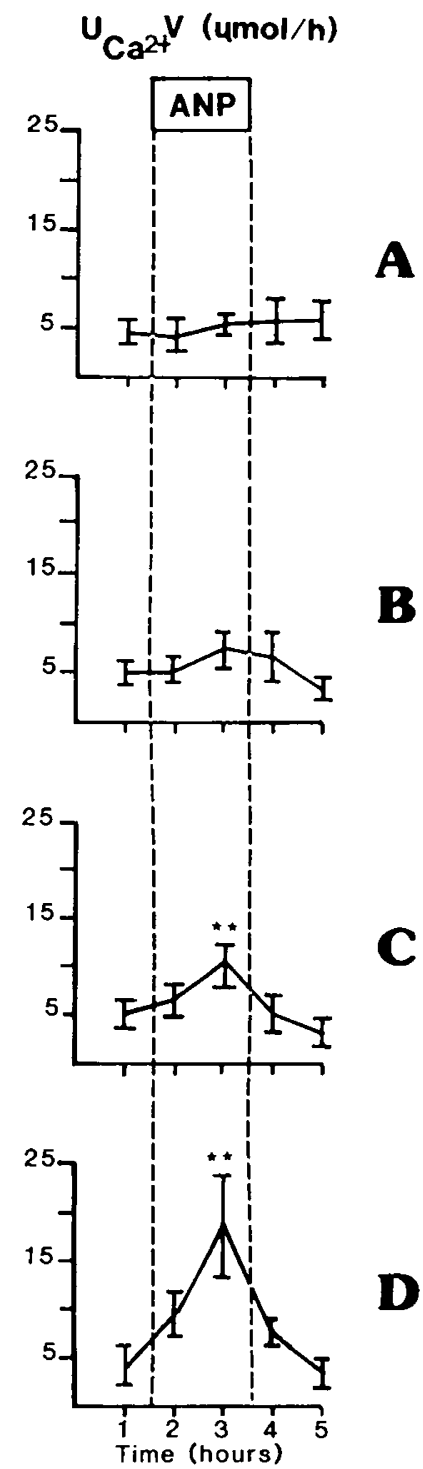

$\mathbf{U}_{\mathrm{CI}^{-}} \mathbf{V}(\mathrm{mmol} / \mathrm{h})$

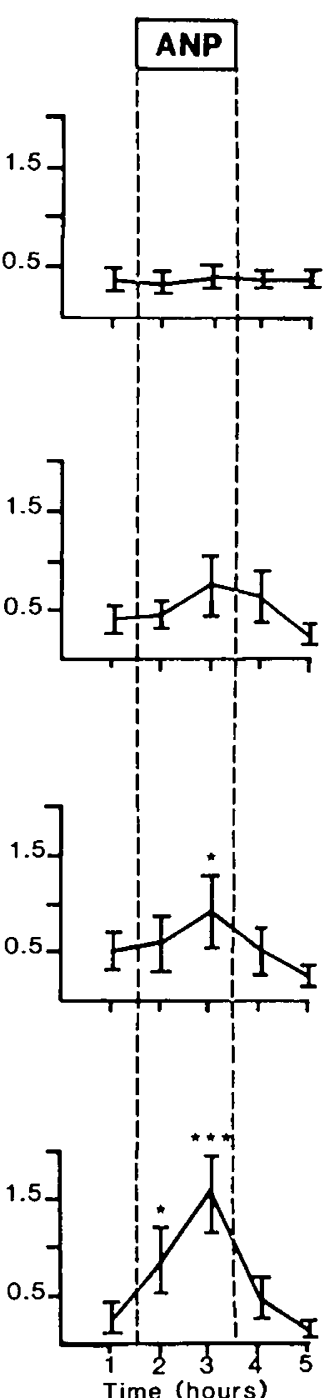

Fig. 3. The values for $\mathrm{U}_{\mathrm{Ca}} \mathrm{V}$ (left) and $\mathrm{U}_{\mathrm{C}} \mathrm{V}$ (right) for ovine fetuses 103-128 days of gestation, infused with hANP at $A, 0(n=10) ; B, 1.1$ $\mu \mathrm{g} / \mathrm{h}(n=4) ; C, 2.2 \mu \mathrm{g} / \mathrm{h}(n=5) ;$ and $D, 4.4 \mu \mathrm{g} / \mathrm{h}(\mathrm{n}=5)$. hANP infusions lasted for $2 \mathrm{~h}$ between the broken lines, after a 1-h control period, and before a $2-\mathrm{h}$ postcontrol period. Values are mean \pm SEM.* ${ }^{*} p$ $<0.05 ;{ }^{* *} p<0.01{ }^{* * *} p<0.001$.

corresponds to an infusion rate of $70-140 \mu \mathrm{g} / \mathrm{h}$ in the adult of $35 \mathrm{~kg}$. When euvolemic conscious adult sheep of the same breed were infused intravenously with hANP at 20,50,100, and 500 $\mu \mathrm{g} / \mathrm{h}$ for 60 min no natriuresis was observed until the $100-\mu \mathrm{g} / \mathrm{h}$ dose. This rate of infusion, into sheep of $35-45 \mathrm{~kg}$, increased urinary sodium excretion from $96 \pm 19$ to $155 \pm 73 \mu \mathrm{mol} / \mathrm{min}$ in four sheep (Parkes $D$, personal communication). Thus it would seem that the kidney of the immature fetus is as responsive, if not more so, as that of the adult. Until the clearance rates of hANP, in both adult and fetus, have been determined, it is not possible to know exactly how these infusions altered the peripheral blood concentrations of the peptides. In the adult the maximum diuresis and natriuresis occur in the $1 \mathrm{st} h$ and the effect decreases, although it is still significant in the $2 \mathrm{nd} \mathrm{h}(15)$. It is not known whether ANP crosses the placenta in the sheep. If it does cross the placenta then it would possibly take more than 1 $h$ for stable blood levels to be achieved by infusion. This could provide one explanation for the difference in time course of maximum effect between the fetus and the adult. If ANP crosses 


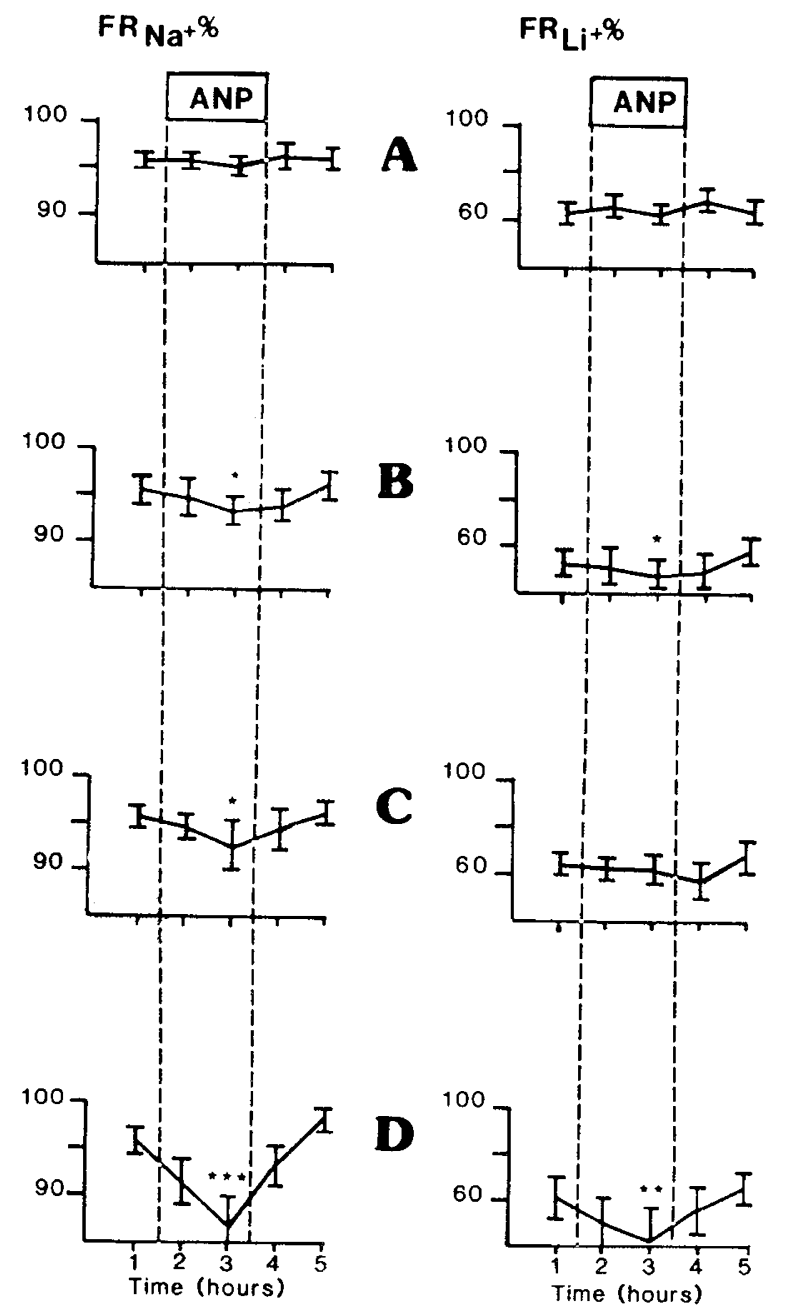

Fig. 4. The fractional reabsorption rates for $\mathrm{Na}$ (left) and $\mathrm{Li}$ (right) in ovine fetuses infused with hANP at varying rates. $A, 0(n=10) ; B, 1.1$ $\mu \mathrm{g} / \mathrm{h}(n=4) ; C, 2.2 \mu \mathrm{g} / \mathrm{h}(n=5) ; D, 4.4 \mu \mathrm{g} / \mathrm{h}(\mathrm{n}=5)$. hANP was infused for $2 \mathrm{~h}$, between the broken lines, following a 1-h control period, and preceding a 2-h postcontrol period. Fetuses were 103-108 days of gestation. Values are mean \pm SEM. ${ }^{*} p<0.05{ }^{* *} p<0.01{ }^{* * *} p<0.001$.

the placenta then the observed results probably occur at an even lower blood concentration in the fetus than in the adult sheep. If blood concentrations of ANP and/or clearance rates were measured this question could be resolved.

The mechanism by which ANP exerts its effects is still a matter of debate. Urinary excretion of electrolytes can be measured with greater accuracy than can GFR. Thus one cannot over interpret the finding that $\mathrm{U}_{\mathrm{Na}} \mathrm{V}$ increased at a lower infusion rate than did GFR. Very small changes in GFR, which did not necessarily reach a level of significance, could still account for the observed increment in $\mathrm{Na}$ excretion, particularly if glomerulotubular balance were disrupted. However, the fact that fractional reabsorption of $\mathrm{Li}$ was decreased quite significantly at the $4.4-\mu \mathrm{g} / \mathrm{h}$ infusion rate, when $\mathrm{Na}$ excretion was increased 5-fold, would suggest that these parameters were linked. As Li reabsorption correlates in some species with $\mathrm{Na}$ reabsorption in the proximal tubule $(11,12)$ it may be that at least some of the effect of hANP in the fetus was due to proximal tubular rejection of $\mathrm{Na}$. A number of studies in adult rats and dogs have concluded that at least part of the natriuresis induced by ANP is associated with decreased proximal tubular reabsorption of sodium (16-18). The fact that $\mathrm{C}_{\mathrm{H} 2 \mathrm{O}}$ increased, in the absence of a drop in urine osmolality, indicates unequivocally that increased delivery of fluid to the distal segments occurred.
As amniotic pressure was not measured simultaneously with arterial pressure it is just possible that no decrease in arterial pressure was seen during hANP infusions because amniotic pressure was simultaneously increasing. This is unlikely, however, as there was no change in HR.

The absence of any change in blood pressure may reflect the absence of vascular receptors in the fetus at this period of gestation. Alternatively, the difference in the fetal and adult circulations may account for lack of effect of hANP. In the adult, conscious sheep, the major circulatory effect of ANP is to lower the cardiac output $(15,19,20)$. With a significant amount of the blood returning to the fetal heart coming from the umbilical vein, it may be that the umbilical vessels lack ANP receptors.

The exaggerated $\mathrm{NaCl}$ loss by the kidney of the premature or very low birth weight neonate has been attributed, in part, to increased delivery of fluid to the distal tubule (2). It has already been shown that increased blood cortisol concentrations can have this effect on the immature kidney (5). Another explanation could be that such infants have high circulating blood levels of ANP. In two recent communications it has been shown that plasma immunoreactive atrial natriuretic peptide is higher in premature, low birth weight infants than in normal term neonates $(21,22)$. In these studies it was not possible to correlate absolute plasma ANP concentrations and urinary sodium excretion, suggesting that not all the immunoreactive peptide was biologically active. However, the present report demonstrates that the immature ovine fetal kidney is fully responsive to infused hANP. It is possible that elevated plasma ANP concentrations do play a part in the control of sodium balance in premature human neonates.

\section{REFERENCES}

1. Al-Dahhan J, Haycock GB, Chantler L, Stimmler L 1983 Sodium homeostatis in term and preterm neonates. I. Renal aspects. Arch Dis Child 58:335-342

2. Rodriquez-Soriano J, Vallo A, Oliveros R, Castillo G 1983 Renal handling of sodium in premature and full-term neonates: a study using clearance methods during water diuresis. Pediatr Res 17:1013-1016

3. Roy RN, Chance GW, Radde IC, Hill DE, Willis DM, Sheepers J 1976 Late hyponatremia in very low birth weight infants. Pediatr Res 10:526-531

4. Sulyok E, Nemeth M, Tenyi I, Csaba I, Gyory E, Ertl T, Varga F 1979 Postnatal development of renin-angiotensin-aldosterone system, RAAS, in relation to electrolyte balance in premature infants. Pediatr Res 13:817-820

5. Wintour EM, Coghlan JP, Towstoless M 1985 Cortisol is natriuretic in the immature ovine fetus. J Endocrinol 106:R13-R15

6. Bell RJ, Congiu M, Hardy KJ, Wintour EM 1985 Gestation-dependent aspects of the response of the ovine fetus to the osmotic stress induced by maternal water deprivation. Q J Exp Physiol 69:187-195

7. Wintour EM, Congiu M, Hardy KJ, Hennessy DP 1982 Regulation of urine osmolality in fetal sheep. Q J Exp Physiol 67:427-435

8. de Bold AJ, Borenstein HB, Veress AT, Sonnenberg H 1981 A rapid and potent natriuretic response to intravenous myocardial extract in rats. Life Sci 28:89-94

9. Kangawa K, Matsuo H 1984 Purification and complete amino acid sequence of human atrial natriuretic polypeptide (hANP). Biochem Biophys Res Commun 118:131-139

10. Cheung CY, Gibbs DM, Brace RA 1986 Atrial natriuretic factor in fetal and maternal plasma, urine and amniotic fluid of sheep. Proceedings of the Society for Gynecologic Investigation, Toronto, March 19-22 (abstr 29)

11. Hayslett JP, Kashgarian M 1979 A micropuncture study of the renal handling of lithium. Pflugers Arch 380:159-163

12. Thomsen K, Schou M 1986 Lithium clearance: a new research area. News Physiol Sci 1:126-128

13. Wintour EM, Bell RJ, Congui M, Macisaac RJ, Wang X 1985 The value of ovine osmolality as an index of stress in the ovine fetus. J Dev Physiol 7:347354

14. Wade JD, Fitzgerald SP, McDonald MR, McDougall JG, Tregear GW 1986 The solid phase synthesis of $\bar{A}$ human atrial natriuretic factor: comparison of the BOC-polystyrene and FMOC-polyamide methods. Biopolymers 25:S21-S37

15. Parkes DG, Coghlan JP, Denton DA, McDougall JG, Scoggins BA 1986 Haemodynamic and renal effects of human atrial natriuretic peptide (1-28) in volume expanded sheep. Proc Aust Physiol Pharmacol Soc 17:68P (abstr)

16. Burnett JC, Granger JP, Opgenorth TJ 1984 Effects of synthetic atrial natriuretic factor on renal function and renin release. Am J Physiol 247:F863F866

17. Hammond TG, Yusufi ANK, Knox FG, Dousa TP 1985 Administration of atrial natriuretic factor inhibits sodium-coupled transport in proximal tubules. J Clin Invest 75:1983-1989 
18. Burnett JC, Opgenorth TJ, Granger JP 1986 The renal action of atrial natriuretic paptide during control of glomerular filtration. Kidney Int 30:16-19

19. McDougall JG, Coghlan JP, Johnston EIM, Parkes DG, Penschow JD, Scoggins BA, Yates NA 1986 The endocrinology of atrial natriuretic peptide (ANP). Proc Endocrinol Soc Aust 29:S(1),10,1-6

20. Breuhaus BA, Sanell HH, Brandt MA, Chimobkey JE 1985 Atriopeptin II lowers cardiac output in conscious sheep. Am J Physiol 249:R776-R780

21. Tulassay $\Upsilon$, Rascher W, Seyberth HW, Lang RE, Toth M, Sulyok E 1986 Role of atrial natriuretic peptide in sodium homeostasis in premature infants. Pediatr 109:1023-1027

22. Shaffer SG, Greer PG. Goetz KL 1986 Elevated atrial natriuretic factor in neonates with respiratory distress syndrome. J Pediatr 109:1028-1033

\section{Announcement}

\section{International Symposium on Surfactant Replacement Therapy}

This symposium will be held on November 14-15, 1987 at the Medical Faculty of Erasmus University, Rotterdam.

Information: Dr. B. Lachmann, Department of Anesthesiology, Erasmus University, Postbox 1738, 3000 DR, Rotterdam, NL. (31) $10-4634393$. 